\title{
Symplastic Glomus Tumor
}

\author{
Simplastik Glomus Tümör
}

\author{
Fevziye KABUKÇUOĞLU' ${ }^{1}$, Hanife ÖZKAYALAR ${ }^{1}$, Damlanur SAKIZ', Yavuz KABUKÇUOĞLU² \\ 'Department of Medical Pathology, Şişli Etfal Education and Research Hospital, ISTANBUL, TURKEY \\ 2Department of Orthopaedics and Traumatology, Metin Sabancı Baltalimanı Bone Diseases Training and Research Hospital, ISTANBUL, TURKEY
}

\begin{abstract}
Glomus tumors showing nuclear pleomorphism without any other malignant features have been defined as symplastic glomus tumors. This type of glomus tumor is rarely encountered. Another case of symplastic glomus tumor is described in this study. A 37-year-old woman referred to the hospital with the complaint of a palpable tender nodule on the fourth finger tip of her left hand. The lesion had been present for about a year and aggravation of tenderness upon cold exposure was conspicuous. It was a $0.5 \mathrm{~cm}$ well circumscribed lesion with round to cuboidal epithelioid cells showing high grade nuclear pleomorphism. Nests of cells more uniform in shape and showing punched out nucleus representative of typical glomus tumor could also be observed. Immunohistochemical study showed expression of smooth muscle actin, caldesmon and vimentin. Ki-67 labeling index was undetectable. Investment of tumor cells was shown by type IV collagen. In contrast to its atypical cellular morphology, symplastic glomus tumor clinically behaves benign, and it is important to differentiate it from malignant glomus tumor as well as other primary or metastatic malignant tumors.
\end{abstract}

Key Words: Glomus tumor, Differential diagnosis, Metastasis

\begin{abstract}
ÖZ
Nükleer pleomorfizm dışında başka bir malignite bulgusu içermeyen simplastik glomus tümörü çok nadirdir. Burada diğer bir simplastik glomus tümörü olgusu sunulmaktadır. Otuzyedi yaşında kadın hasta, sol el 4. parmak ucunda ağrılı nodül nedeni ile hastaneye başvurmuştur. Kitlenin bir yıldır mevcut olup, soğuğa maruz kalma ile ağrısının arttığı bildirilmiştir. İyi sınırlı 0,5 cm çapındaki kitlenin histopatolojik incelenmesinde, ileri derecede nükleer pleomorfizm gösteren yuvarlak ya da kübik şekilli epiteloid hücrelerden oluşan lezyon görülmüştür. Yer yer tipik glomus tümörünü temsil eden uniform şekilli, çevresinde halo içeren santral nükleuslu hücre grupları da izlenmiştir. İmmünohistokimyasal çalışmada düz kas aktini, kaldesmon ve vimentin ile boyanma görülmüştür. Ki-67 ile boyanma izlenmemiştir. Tip IV kollajen ile tümör hücrelerinin tek tek sarıldığı dikkati çekmiştir. Atipik, sellüler morfolojisine karşılık simplastik glomus tümörü klinik olarak benign davranır; bu nedenle malign glomus tümörü yanı sıra diğer primer ve metastatik malign tümörler ile ayrımı önemlidir.
\end{abstract}

Anahtar Sözcükler: Glomus tümörü, Ayırıcı tanı, Metastaz

\section{INTRODUCTION}

Glomus tumors are mesenchymal neoplasms composed of cells closely resembling the modified smooth muscle cells of the normal glomus body which is a specialized arteriovenous shunt involved in temperature regulation. They constitute less than $2 \%$ of the soft tissue tumors $(1,2)$. The majority of these tumors are small red blue nodules that occur in the dermis or subcutis of the distal extremities, particularly in the subungual region, the hand, the wrist and the foot. A long history of pain especially with exposure to cold or minor tactile stimulation is characteristic (3-5). Although the features of the tumor are distinctive, diagnosis can be occasionally conflicting because of unusual features such as large size, deep soft tissue or visceral location, infiltrative growth pattern, pleomorphism and mitotic activity $(6,7)$. Rare examples of malignant glomus tumors have been

(Turk Patoloji Derg 2015, 31:211-214)

Received : 17.12.2011 Accepted : 21.01.2012 reported, while some have been classified as glomus tumor of uncertain malignant potential (8-10). Furthermore, a form of glomus tumor that shows striking nuclear atypia without any other malignant features has been designated as symplastic glomus tumor (6). There have been only few case reports of this type of glomus tumor presented in the literature up to date (11-13). The authors report another example of the symplastic glomus tumor in the left fourth finger tip of a 37-year-old woman.

\section{CASE REPORT}

A 37-year-old woman presented with the complaint of a palpable tender nodule on the fourth finger tip of her left hand. The mass was $0.5 \mathrm{~cm}$ in diameter and had been present for about a year. The patient emphasized aggravation of tenderness upon cold exposure. There was no history of trauma. Gross examination of the excised material

Correspondence: Fevziye KABUKÇUOĞLU

Şişli Hamidiye Etfal Eğitim ve Araştırma Hastanesi, Tibbi Patoloji Kliniği,

Halaskargazi Cad. Etfal Sk. 34371, Şişli, İSTANBUL, TURKEY

E-mail: fkabukcuoglu@hotmail.com Phone: +90 2122316671 
showed a bluish red nodule measuring $0.5 \times 0.3 \times 0.2 \mathrm{~cm}$. Histopathological examination showed a well circumscribed tumor involving the dermis and subcutaneous tissue. The tumor was composed of capillary sized blood vessels surrounded by a solid proliferation of round to cuboidal epithelioid cells with centrally placed, sharply punched out round nucleus and eosinophilic cytoplasm. Most of the cells showed marked nuclear pleomorphism and atypia with occasional bizarre nuclei. Intranuclear inclusions were noted in some of the pleomorphic cells. Nests of typical glomus cells could be observed next to atypical areas (Figure 1A,B). No mitosis or necrosis was observed. The stroma between the tumor islands was hyalinized with focal myxoid change. The surgical margins were free of tumor. Immunohistochemically the tumor cells were positive for smooth muscle actin, caldesmon and vimentin (Figure 2A,B). CD34 showed focal staining. Investment of tumor cells was shown by type IV collagen (Figure 2C). No staining was observed for CK, HMB45, Melan A and S100. Ki67 labeling index was less than 1\%. S100 staining showed numerous nerve structures transversing the tumor. The case was interpreted as symplastic glomus tumor. There was no recurrence in one year follow-up of the patient.

\section{DISCUSSION}

Glomus tumors are quite distinctive with their characteristic morphology, location and symptoms, but rarely they may display unusual clinical or histopathological features. Rare cases have been interpreted as malignant glomus tumor on the basis of nuclear atypia, necrosis and mitotic activity (8$10)$. The largest series of atypical glomus tumors has been constituted by Folpe et al (6). Criteria for malignancy have been defined based on the analysis of 52 cases for size, depth, growth pattern, cellularity, nuclear grade, number of mitotic figures, vascular space involvement and necrosis. They have suggested the term "malignant glomus tumor" to be reserved for tumors with a marked risk of metastasis. Such lesions fulfill at least one of the following: deep location and size more than $2 \mathrm{~cm}$, or presence of atypical mitotic figures or marked nuclear atypia with mitotic figures $>5 / 50 \mathrm{HPF}$.

In Folpe's study, glomus tumors not fulfilling criteria for malignancy but having at least one atypical feature other than nuclear pleomorphism were categorized as "glomus tumors of uncertain malignant potential" (6). Tumors in this category are superficial tumors with high mitotic activity or they are large or deep. Glomangiomatosis was used for tumors with diffuse angiomatosis and excess glomus cells. Finally, the term "symplastic glomus tumor" was proposed for glomus tumors with high nuclear grade in the absence of any other malignant feature. Nine of the cases were classified as symplastic glomus tumor in the series. Two of them showed recurrence and none of them metastasized. They concluded that these tumors were benign similar to ordinary glomus tumors.

The marked nuclear atypia in glomus tumors is similar to that seen in some benign mesenchymal tumors of long duration, especially uterine leiomyoma and ancient schwannoma. These tumors behave like ordinary leiomyomas and schwannomas, therefore the nuclear atypia has been accepted as a degenerative change $(1,6,14)$.
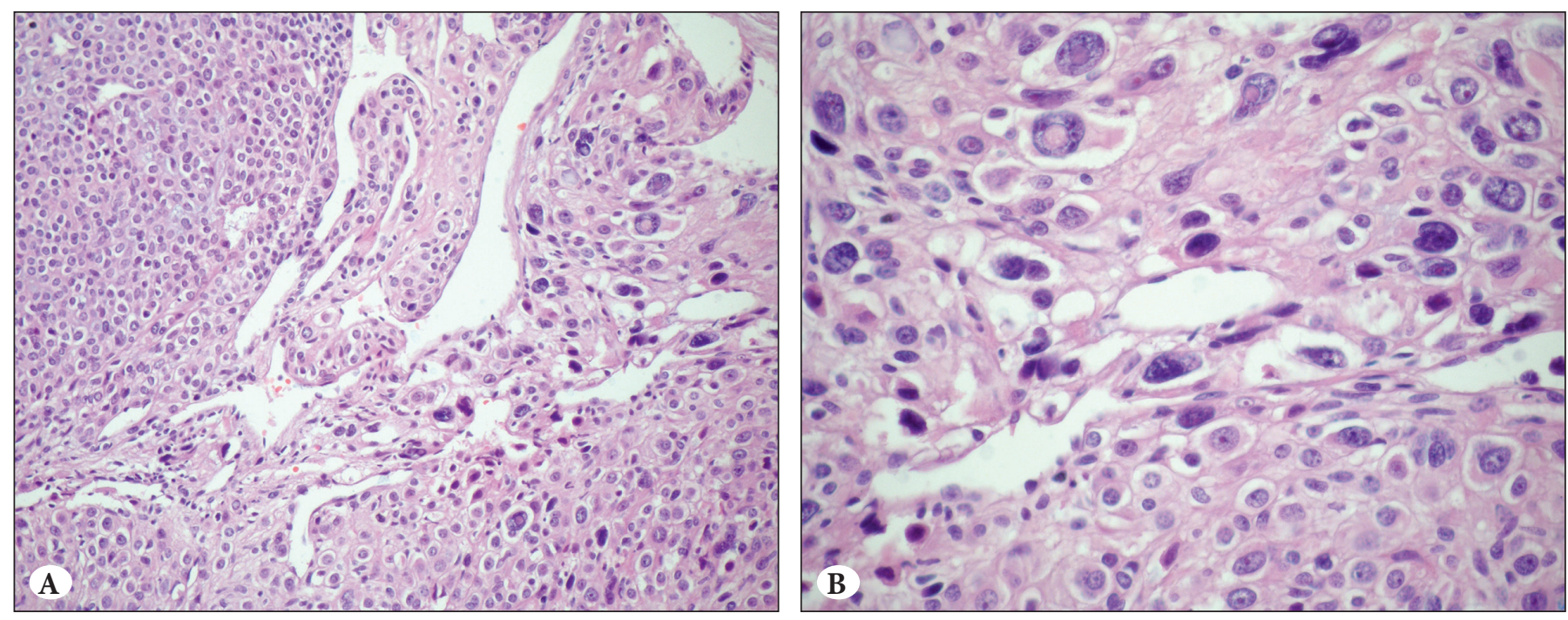

Figure 1: A) Tumor composed of cells showing perivascular orientation and pronounced pleomorphism. A nest of typical glomus cells is noted at the left (H\&E, x200). B) Round to cuboidal epithelioid cells with central punched out nuclei showing high grade nuclear pleomorphism. (H\&E, x400). 

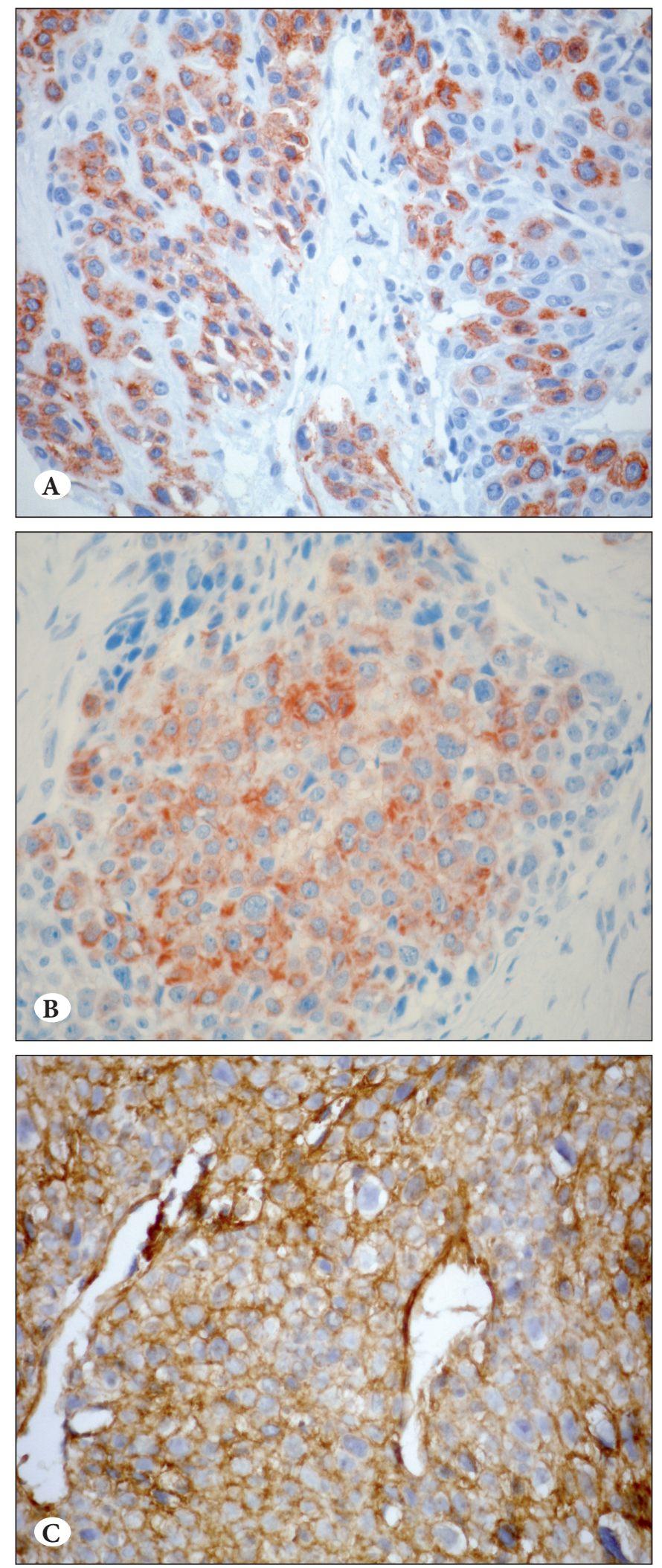

Figure 2: A) The expression of smooth muscle actin by tumor cells (SMA; x400). B) The expression of caldesmon by tumor cells (Caldesmon; x400). C) The investment of tumor cells by type IV collagen (Type IV collagen; $\mathrm{x} 400$ ).
The tumor cells of the presented case showed striking nuclear atypia, some with bizarre nuclei. Although the pleomorphism and the epithelioid configuration of the tumor were alarming at the initial evaluation, malignancy was not in the foreground because neither mitotic activity nor necrosis was present and Ki-67 labeling index showed that the proliferative activity was undetectable. While typical glomus tumor areas were only focal, the punched out appearance of tumor cells could be identified even at the atypical areas. Type IV collagen pattern and smooth muscle actin staining were consistent with symplastic glomus tumor. The morphology together with the clinical symptoms confirmed the diagnosis.

The evaluation of symplastic glomus tumors needs careful histopathological examination $(1,5,6)$. Marked nuclear atypia of the tumor may be reminiscent of a malignant tumor. Epithelioid appearance of the tumor may be misleading. While the identification of areas of typical glomus tumor is the most important clue to the diagnosis, these areas may be minimal or absent in some cases. The branching capillaries and the perivascular arrangement of tumor cells should be noted. Immunohistochemical study showing smooth muscle actin expression and type IV collagen, a constituent of basal lamina, outlining the cells are the most beneficial in histopathological diagnosis especially when the typical glomus tumor areas are not distinctive (1). Lack of expression by cytokeratins helps to eliminate a primary or a metastatic epithelial tumor and adnexial tumors. HMB45 and S100 negativity allow distinction from malignant melanoma. Despite its atypical morphology, symptoms and location are quite typical in most cases of symplastic glomus tumor, thus it is important to get thorough clinical history.

Symplastic glomus tumor is considered benign with occasional recurrences due to incomplete excision. Recognition of this rare morphologic deviation is critical, as the marked atypia can lead to an incorrect diagnosis of malignancy and overtreatment.

\section{REFERENCES}

1. Weiss SW, Goldblum JR. Perivascular tumors. In : Enzinger and Weiss's Soft Tissue Tumors. 5th ed., Philadelphia: Mosby; 2008. 751-67.

2. Folpe AL. Glomus tumors. In : Fletcher CDM, Unni KK, Mertens F. editors. World Health Organization Classification of Tumours, Pathology \& Genetics, Tumours of Soft Tissue and Bone. 1st ed. Lyon: IARC Press, 2002. 136-7.

3. Gombos Z, Zhang PJ. Glomus tumor. Arch Pathol Lab Med. 2008;132:1448-52. 
4. Heys SD, Brittenden J, Atkinson P, Eremin O. Glomus tumour: An analysis of 43 patients and review of the literature. Br J Surg. 1992;79:345-7.

5. Mc Kee PH, Calonje E, Granter SR. Pathology of the Skin with Clinical Correlations. 3rd ed. Philadelphia: Elsevier Mosby; 2005. 1848-51.

6. Folpe AL, Fanburg-Smith JC, Miettinen M, Weiss SW. Atypical and malignant glomus tumors: Analysis of 52 cases, with a proposal for the reclassification of glomus tumors. Am J Surg Pathol. 2001;25:1-12.

7. Pulitzer DR, Martin PC, Reed RJ. Epithelioid glomus tumor. Hum Pathol. 1995;26:1022-7.

8. Khoury T, Balos L, McGrath B, Wong MK, Cheney RT, Tan D. Malignant glomus tumor: A case report and review of literature, focusing on its clinicopathologic features and immunohistochemical profile. Am J Dermatopathol. 2005; 27:428-31.

9. Cibull TL, Gleason BC, O’Malley DP, Billings SD,Wiersema P, Hiatt KM. Malignant cutaneous glomus tumor presenting as a rapidly growing leg mass in a pregnant woman. J Cutan Pathol. 2008;35:765-9.
10. Hiruta N, Kameda N, Tokudome T, Tsuchiya K, Nonaka H, Hatori T, Akima M, Miura M. Malignant glomus tumor: A case report and review of the literature. Am J Surg Pathol. 1997; 21:1096-103.

11. Kamarashev J, French LE, Dummer R, Kerl K. Symplastic glomus tumor- a rare but distinct benign histological variant with analogy to other "ancient" benign skin neoplasms. J Cutan Pathol. 2009;36:1099-102.

12. Chong Y, Eom M, Min HJ, Kim S, Chung YK, Lee KG. Symplastic glomus tumor: A case report. Am J Dermatopathol. 2009;31:71-3.

13. Arsenovic N, Ramaiya A, Moreira R. Symplastic glomangioma: Information review and addition of a new case. Int J Surg Pathol. 2011;19:499-501.

14. Usmani N, Merchant W, Yung A. A case of cutaneous symplastic leiomyoma - a rare variant of cutaneous pilar leiomyoma. J Cutan Pathol. 2008;35:329-31. 